\title{
Use of Graph Model for the Resolution of Conflicts between Fishers of the Amazonian Floodplain Lakes
}

\author{
Fabíola A. Nascimento ${ }^{1}$ \& Carlos E. C. Freitas ${ }^{2}$ \\ 1 UNINORTE - Laureate International Universities, Manaus, Brazil. Uninorte (unidade 12), Av. Leonardo \\ Malcher, n. 1146 - Centro, Manaus, Brazil \\ 2 Department of Fisheries Sciences, Federal University of Amazonas, Manaus, Brazil \\ Correspondence: Carlos E. C. Freitas, Department of Fisheries Sciences, Federal University of Amazonas, \\ 69077-000. Manaus, Brazil. Tel: 55-92-3305-4063. E-mail: cefreitas@ufam.edu.br
}

Received: October 10, 2012 Accepted: November 26, 2012 Online Published: November 30, 2012

doi:10.5539/enrr.v3n1p16

URL: http://dx.doi.org/10.5539/enrr.v3n1p16

\begin{abstract}
We evaluated the GMCR II (Model of the Graphs for Conflict Resolution) as a tool for the identification of fishing management strategies that could be possible solutions for fishing conflicts in the floodplain lakes of the Central Amazon. The procedures of this software are based on the Graph Theory, a mathematical approach derived from the Game Theory. In our modeling, the players were IBAMA (environmental agency in Brazil), commercial fishers and subsistence fishers. The GMCR II demonstrated that when IBAMA adopts the strategy of restriction of some fishing gear in floodplain lakes, the resolution of the conflict between fishers is more likely to happen. We also conclude that the use of a mathematical approach, by the employment of the GMCR II, would be an important tool for approaching conflict situations but that its use needs to be followed by other methodologies, mainly participative programs.
\end{abstract}

Keywords: fishing conflict, management, small-scale fisheries, Amazon Basin, GMCR II

\section{Introducation}

Negotiation is a common human process whose importance is evidenced by the enormous amount of advice and expertise that is available to assist negotiators. Mathematical models have been used to help these negotiators to study behavior in conflicts; these include Metagame Analysis (Howard, 1971) and the Graph Model for Conflict Resolution (Fang, Hipel, \& Kilgour, 1993). The last one of these models is an expansion and reformulation of Conflict Resolution (Fang et al., 1993) and Metagame Analysis is a comprehensive methodology for the systematic study of strategic conflicts arising in the real world (Fang et al., 1993).

The Graph Model for Conflict Resolution is based on rigorous mathematical structures using concepts from Graph Theory and Groups of Logical Theories as well as Mathematics of Relationship and Game Theory (as multiple-objective users are utilized) (Kilgour, Hipel, \& Fang, 1987). This model enables the systematic study of a conflict that involves two or more decision-makers and shows their possible solutions. The results can be used, for instance, to provide support for decision makers.

In a conflict, two or more groups are in dispute over an issue such as the allocation of scarce resources (Kilgour et al., 1987). In the Amazon Basin, subsistence and commercial fishers have been in conflict for fish resources for decades, mostly over floodplain lakes due to their large fish stocks (Junk, 2000). As a primary cause of this conflict, in the last three decades, riverine people, who are subsistence fishers, are prohibiting access of external community fishers to and/or commercial fishing activity in this environment because they intend to preserve this important source of animal protein (Batista, Inhamuns, Freitas, \& Freire-Brasil, 1998). Consequently, the closure of such lakes has become a major cause of fishing conflicts in areas of the Amazon region (McGrath, Castro, Futemma, Amaral, \& Calabria, 1993).

Since 2002, the Brazilian environmental agency, IBAMA, has mediated several agreements between subsistence and commercial fishers with the goal of reducing these fishing conflicts in the region. Nevertheless, for the fishing agreements to be successful, some conditions are necessary: all of the different groups of fishers have to agree over management strategies included on it, there must be a presence of strong social structures (Berkes, 2003) and a real perception of welfare improvement (Sobreiro et al., 2010) and these strategies have to be able to 
protect the fishing resources. Therefore, it is essential to find consensual rules governing the use of fishing resources in the floodplain lakes that mitigate the conflicts among the fisher's types. Therefore, this paper focuses on the use of the Graph Model for Conflict Resolution as a strategy to manage conflicts over fishing in the Amazonian floodplain lakes.

\section{Method}

The decision support system GMCR II was used to obtain possible solutions for the fishing conflicts in the Amazon Basin. The methodology of this model mainly consisted of modeling, analysis of the stability and identification of the equilibrium. For the modelling, we established as actors the subsistence and commercial fishers, who exploit the fishing resources in the floodplain lakes in the Central Amazon Basin, and the Brazilian environmental protection agency IBAMA. This last actor was chosen because it is the regulatory agency for the implementation of fishery management in Brazil. The actors are classified as individual decision-makers who are able to express several options, which can be designated as strategies (Table 1).

Table 1. Possible strategies of decision-makers in the face of a potential conflict situation over the fishing resources in the Amazon Basin between commercial fisher (CF) and subsistence fisher (SF)

\begin{tabular}{lll}
\hline Decision-maker & Strategies & Abbreviation \\
\hline IBAMA & - Restrict the use of fishing gears & - Restrict fishing \\
& - Prohibit the activity of commercial fishing & - Prohibit CF \\
& - Do anything & - Do anything \\
Commercial Fisher & - Accept IBAMA's decision & - Accept decision \\
& - Increase fishing pressure in the lake & - Increase fishing \\
Subsistence Fisher & - Accept IBAMA's decision & - Accept decision \\
& - Prohibit commercial fishing & - Prohibit fishing \\
\hline
\end{tabular}

IBAMA's strategies to restrict the use of fishing gears or prohibit the activity of commercial fishing were obtained through research using secondary data (fishing agreements that were made in Amazonas state between 2002 and 2006). The strategy of no action was included in the modelling process, as this is a common situation in the Amazon due to the large territorial area and the clear absence of the government authorities. The strategies chosen by the commercial and subsistence fishers were adopted vis-à-vis the potential reactions of these actors to the strategies adopted by IBAMA. Therefore, we assume that these two actors were able to decide "whether or not to accept the strategies adopted by IBAMA".

After selecting the actors and their strategies, we founded the potential situation as a group of strategy combinations selected by all decision makers. However, not all of the combinations were viable; consequently, some combinations were excluded from the model. The criteria employed to take the decision of exclude strategies were: conflicting strategies cannot be chosen at the same time and/or that the decision-makers wouldn't be able to choose two strategies at same time. The next step of this model was identifying the decision-maker's preferences towards scenarios of the conflict, that is, the payoff functions. These were inferred as follows.

For IBAMA, we have some hypotheses for ranking the scenarios:

(i) First, this agency is more interested in resolving the fishing conflict in the floodplain lake than it is in the ecological management of the resource. We can call this a social management option. Consequently, IBAMA has a preference for the choice of "restricting fishing gears", and both commercial fishers and subsistence fishers were willing accept such a strategy;

(ii) Second, IBAMA is interested in the protection of the lake's fishery resources. We can call this ecological management. To ensure the protection of fishery resources, the strategy "prohibit the commercial fishing" is IBAMA's strategy preference in the floodplain lake, but it is unacceptable for commercial fishers.

(iii) Third, "do anything" is an antithesis to IBAMA's main goal.

For the subsistence of fishers, IBAMA's involvement in fishing management is essential because it brings legal support for the effort to preserve the resources of the lake, which is the main supplier of animal protein in the 
area. Consequently, the best scenario for the subsistence fishers is the one in which the manager decides to prohibit commercial fishing in the floodplain lake. In case IBAMA fails to take any action towards fishing in the floodplain lake, the riverine people will unilaterally decide to prohibit the access of commercial fishers to the lake to prevent the escalation of fishing pressure at the lake.

For the commercial fishers, the best scenario is for IBAMA to enforce no actions in connection with fishing in the floodplain lakes because they believe that IBAMA deliberates on behalf of the subsistence fishers by prohibiting for the most part the practice of commercial fishing in these places. However, if the agency decides to establish the use of regulations, the only acceptable strategy for these commercial fishers will be the restriction of some fishing gears.

The GMCR II can calculate the stability of every state, from each decision-maker's viewpoint, for a rich range of human-conflict decision patterns. A state is stable for a decision maker if and only if that decision maker has no incentive to deviate unilaterally under a particular behavioral model; this is usually referred to as a stability definition or solution concept (Kilgour, Hipel, \& Fang, 1987) (Table 2). A variety of solution concepts must be defined to model various patterns of conflict behavior and thereby reflect diverse strategic decision styles from cautious and conservative to prognosticative and manipulative (Fang, Hipel, Kilgour \& Peng. 2003).

Finally, we developed an analysis of equilibrium assuming that a state is an equilibrium or possible resolution under a particular stability definition if all decision makers find stability under that stability definition. To evaluate the robustness of the equilibrium of this possible resolution, a sensibility analysis was performed. In other words, some preferences of individual decision makers were randomly changed. After these changes, the model was run again, and the scenarios that remained in balance were considered to be more robust.

Table 2. Behavior models used in the GMCR II to determine the stability of each state for every decision-maker

\begin{tabular}{ll}
\hline Solution Concepts & Explanation \\
\hline Nash Stability & $\begin{array}{l}\text { Focal decision-maker cannot move unilaterally to a more preferred state } \\
\text { (Nash, 1951; von Neumann \& Morgenstern, 1953). }\end{array}$ \\
General Metarationality & $\begin{array}{l}\text { All of the focal decision-maker's unilateral improvements are sanctioned } \\
\text { by subsequent unilateral moves by the other decision maker (Howard, } \\
\text { 1971). }\end{array}$ \\
Symmetric Metarationality & $\begin{array}{l}\text { All of the focal decision-maker's unilateral improvements are sanctioned } \\
\text { even after responses by the focal decision-maker (Howard, 1971). }\end{array}$ \\
Sequential Stability & $\begin{array}{l}\text { All of the focal decision-maker's unilateral improvements are sanctioned } \\
\text { by subsequent unilateral improvements by the other decision-maker } \\
\text { (Fraser \& Hipel, 1979; Howard, 1971). }\end{array}$ \\
Limited-mode Stability & $\begin{array}{l}\text { All of the focal decision-makers are assumed to act optimally within a } \\
\text { specified number of state transitions (Kilgour et al., 1987; Zagare, 1994). }\end{array}$ \\
Non-myopic Stability & $\begin{array}{l}\text { Limiting case of limited-move stability as the maximum number of } \\
\text { scenarios transitions increases to infinity (Kilgour et al., 1987; Brams } \\
\text { 1994). }\end{array}$ \\
\hline
\end{tabular}

\section{Results}

\subsection{States}

A total of 128 scenarios were found that reflect all possible combinations based on these decisions. However, after using criteria to determine the unviable scenarios, which are that strategies cannot be chosen at the same time or that actors wouldn't be able to choose two strategies at same time, and determining that at least one strategy could be chosen in each situation, we ended up with only 12 scenarios, which were called viable scenarios (Table 3). The first column on Table 3 shows the strategies used for this simulation, and the remaining columns show the viable scenarios. These scenarios are represented by the letters "Y" and "N", indicating the qualification and disqualification of a given strategy, respectively. For instance, in the first viable scenario (second column), the letters are distributed as follows: YNNYNYN, which means, in this case, that if IBAMA chooses to restrict the use of fishing gears in the lake, subsistence and commercial fishers will agree with its decision. 
After the identification of viable scenarios for a conflict, the occurrence of unilateral movements/actions from each decision maker among the scenarios is possible; these movements are called transition scenarios (Table 4). All of the movements of the actors and managers can be considered reversible, and the results show that both commercial fishers and subsistence fishers do not have many shift options. We can see that both types of fishers can make just one unilateral movement (Table 4).

Analysis of IBAMA's payoff function

First hypothesis - P1(q)

When the data are analyzed based on the first of the hypotheses regarding IBAMA, it is possible to observe four scenarios that have the largest preference payoffs (scenarios 1,2,3 and 4). These scenarios are characterized by the choice of the strategy to restrict the use of fishing gears (Table 4). Within these scenarios, the favorite for the manager is scenario 1 , as both types of fishers agree with this strategy. Additionally, the opposite scenarios, which are scenarios 8 and 12, are shown to be the least favorite in this section (Table 4). These scenarios depict conflict between fishers because of the strategies chosen in these cases (prohibit the activity of commercial fishing and do anything, respectively).

Table 3. Viable States for the fishing conflict in the Amazon floodplain lake (Y-Chosen strategy; N-contrary)

\begin{tabular}{|c|c|c|c|c|c|c|c|c|c|c|c|c|}
\hline \multirow[b]{2}{*}{ Strategies } & \multicolumn{11}{|c|}{ Viable States } & \multirow[b]{2}{*}{12} \\
\hline & 1 & 2 & 3 & 4 & 5 & 6 & 7 & 8 & 9 & 10 & 11 & \\
\hline Restrict the use of fishing gears & $\mathrm{Y}$ & $\mathrm{Y}$ & $\mathrm{Y}$ & $\mathrm{Y}$ & $\mathrm{N}$ & $\mathrm{N}$ & $\mathrm{N}$ & $\mathrm{N}$ & $\mathrm{N}$ & $\mathrm{N}$ & $\mathrm{N}$ & $\mathrm{N}$ \\
\hline $\begin{array}{c}\text { Prohibit the activity of commercial } \\
\text { fishing }\end{array}$ & $\mathrm{N}$ & $\mathrm{N}$ & $\mathrm{N}$ & $\mathrm{N}$ & $\mathrm{Y}$ & $\mathrm{Y}$ & $\mathrm{Y}$ & $\mathrm{Y}$ & $\mathrm{N}$ & $\mathrm{N}$ & $\mathrm{N}$ & $\mathrm{N}$ \\
\hline Do anything & $\mathrm{N}$ & $\mathrm{N}$ & $\mathrm{N}$ & $\mathrm{N}$ & $\mathrm{N}$ & $\mathrm{N}$ & $\mathrm{N}$ & $\mathrm{N}$ & $\mathrm{Y}$ & $\mathrm{Y}$ & $\mathrm{Y}$ & $\mathrm{Y}$ \\
\hline Accept IBAMA's decision & $\mathrm{Y}$ & $\mathrm{N}$ & $\mathrm{Y}$ & $\mathrm{N}$ & $\mathrm{Y}$ & $\mathrm{N}$ & $\mathrm{Y}$ & $\mathrm{N}$ & $\mathrm{Y}$ & $\mathrm{N}$ & $\mathrm{Y}$ & $\mathrm{N}$ \\
\hline Increase fishing pressure in the lake & $\mathrm{N}$ & $\mathrm{Y}$ & $\mathrm{N}$ & Y & $\mathrm{N}$ & $\mathrm{Y}$ & $\mathrm{N}$ & $\mathrm{Y}$ & $\mathrm{N}$ & $\mathrm{Y}$ & $\mathrm{N}$ & $\mathrm{Y}$ \\
\hline Accept IBAMA's decision & $\mathrm{Y}$ & $\mathrm{Y}$ & $\mathrm{N}$ & $\mathrm{N}$ & $\mathrm{Y}$ & $\mathrm{Y}$ & $\mathrm{N}$ & $\mathrm{N}$ & $\mathrm{Y}$ & $\mathrm{Y}$ & $\mathrm{N}$ & $\mathrm{N}$ \\
\hline Prohibit commercial fisheries & $\mathrm{N}$ & $\mathrm{N}$ & $\mathrm{Y}$ & $\mathrm{Y}$ & $\mathrm{N}$ & $\mathrm{N}$ & $\mathrm{Y}$ & $\mathrm{Y}$ & $\mathrm{Y}$ & $\mathrm{N}$ & $\mathrm{Y}$ & $\mathrm{Y}$ \\
\hline
\end{tabular}

Table 4. Transition States to every decision-makers on the fishing conflict. Where S1(q)-transition states to the IBAMA; S2 (q)-transition states to the commercial fishing; S3(q)-transition states to the subsistence fishing; P1(q)-IBAMA's preference for every scenario, on the first hypothesis; P1(q)'-IBAMA's preference for every scenario, on the second hypothesis; P2(q)-preference to the commercial fishing for every scenario; P3(q)preference to the subsistence fishing for every scenario

\begin{tabular}{|c|c|c|c|c|c|c|c|c|c|}
\hline \multirow[t]{2}{*}{ Scenarios (q) } & \multicolumn{2}{|c|}{ Viable States } & \multirow[b]{2}{*}{$\mathrm{S}_{1}(\mathrm{q})$} & \multirow[b]{2}{*}{$\mathrm{S}_{2}(\mathrm{q})$} & \multirow[b]{2}{*}{$\mathrm{S}_{3}(\mathrm{q})$} & \multirow[b]{2}{*}{$\mathrm{P}_{1}(\mathrm{q})$} & \multirow[b]{2}{*}{$P_{1}(q) '$} & \multirow[b]{2}{*}{$\mathrm{P}_{2}(\mathrm{q})$} & \multirow[b]{2}{*}{$P_{3}(q)$} \\
\hline & IBAMA & $\mathrm{CF}$ & & & & & & & \\
\hline 1 & \multicolumn{2}{|c|}{$(\mathrm{YNN}) \times(\mathrm{YN}) \times(\mathrm{YN})$} & 5,9 & 2 & 3 & 12 & 8 & 9 & 10 \\
\hline 2 & \multicolumn{2}{|c|}{$(\mathrm{YNN}) \times(\mathrm{NY}) \times(\mathrm{YN})$} & 6,10 & 1 & 4 & 10 & 4 & 10 & 6 \\
\hline 3 & \multicolumn{2}{|c|}{$(\mathrm{YNN}) \times(\mathrm{YN}) \mathrm{x}(\mathrm{NY})$} & 7,11 & 4 & 1 & 11 & 7 & 5 & 9 \\
\hline 4 & \multicolumn{2}{|c|}{$(\mathrm{YNN}) \mathrm{x}(\mathrm{NY}) \mathrm{x}(\mathrm{NY})$} & 8,12 & 3 & 2 & 9 & 3 & 6 & 5 \\
\hline 5 & \multicolumn{2}{|c|}{$(\mathrm{NYN}) \times(\mathrm{YN}) \times(\mathrm{YN})$} & 1,9 & 6 & 7 & 7 & 12 & 1 & 12 \\
\hline 6 & \multicolumn{2}{|c|}{$(\mathrm{NYN}) \times(\mathrm{NY}) \times(\mathrm{YN})$} & 2,10 & 5 & 8 & 3 & 10 & 3 & 8 \\
\hline 7 & \multicolumn{2}{|c|}{$(\mathrm{NYN}) \times(\mathrm{YN}) \times(\mathrm{NY})$} & 3,11 & 8 & 5 & 5 & 11 & 2 & 11 \\
\hline 8 & \multicolumn{2}{|c|}{$(\mathrm{NYN}) \mathrm{x}(\mathrm{NY}) \mathrm{x}(\mathrm{NY})$} & 4,12 & 7 & 6 & 1 & 9 & 4 & 7 \\
\hline 9 & \multicolumn{2}{|c|}{$(\mathrm{NNY}) \times(\mathrm{YN}) \times(\mathrm{YN})$} & 1,5 & 10 & 11 & 8 & 6 & 11 & 3 \\
\hline 10 & \multicolumn{2}{|c|}{$(\mathrm{NNY}) \times(\mathrm{NY}) \times(\mathrm{YN})$} & 2,6 & 9 & 12 & 4 & 2 & 12 & 1 \\
\hline 11 & \multicolumn{2}{|c|}{$(\mathrm{NNY}) \mathrm{x}(\mathrm{YN}) \mathrm{x}(\mathrm{NY})$} & 3,7 & 12 & 9 & 6 & 5 & 7 & 4 \\
\hline 12 & \multicolumn{2}{|c|}{$(N N Y) \times(N Y) \times(N Y)$} & 4,8 & 11 & 10 & 2 & 1 & 8 & 2 \\
\hline
\end{tabular}


Second hypothesis- P1(q)'

In this hypothesis, the scenarios with the largest payoffs are scenarios 5, 6,7 and 8 . They are characterized by the choice of the strategy prohibiting commercial fishing (Table 4). In this hypothesis, IBAMA wants to resolve conflict between subsistence and commercial fishers; therefore, its favorite scenario is 5 because commercial and subsistence fishers agree with this strategy. The opposite scenarios are 12 and 10; in these scenarios, IBAMA chooses to act (Table 4).

Payoff Function of the commercial fishers-P2(q)

The scenarios most preferred by the commercial fisher are scenarios 1, 2, 9, and 10, in which the subsistence fisher accept the decision made by IBAMA. In scenarios 1 and 2, IBAMA picks the strategy of restricting the use of fishing gears, the single strategy that IBAMA can choose with which the commercial fisher will agree. Scenarios 9 and 10 are the most preferred by the commercial fishers because the agency manager decides not to take any action in connection with the fishing activity in the floodplain (Table 4).

Payoff Function of the subsistence fisher-P3(q)

Scenarios 1, 3, 5 and 7 are those with the largest payoffs for the subsistence fisher and are characterized by IBAMA accepting the fisher's strategies. Therefore, subsistence fisher have two scenarios that could be assumed to resolve conflict (scenarios 1 and 5) because the strategies in which IBAMA chooses to restrict use of fishing gears and prohibit commercial fishing are satisfactory for these actors. Among all of these scenarios, the greatest payoff comes when IBAMA adopts the strategy prohibit commercial fishing (scenarios 5 and 7). The least preferred scenarios are those in which the restrict fishing gears option was selected (scenarios 1 and 3) (Table 4).

\subsection{Stability Analysis}

For each decision maker, the stable scenarios based on IBAMA's previously described preferences were obtained. For the commercial fisher, the stable scenarios were, in increasing order, $\mathrm{q}=10,9,2,1,12,11,4,3,6,5$ and 8 . Among these scenarios, the favorite of commercial fisher is the one in which IBAMA takes no action regarding fishing activity at the floodplain lake (scenario 10). This result can indicate that this decision maker is not interested in modifying the conflict situation. Scenarios 1 and 5 could represent solutions for the fishing conflict because both groups of fishers accept IBAMA's strategy in these states. However, they are weaker scenarios because they are not stable in all stability criteria. Nonetheless, it is observed that when the manager has a preference for the resolution of the conflict among the users of the lake (Hypothesis 1), scenario 1 is stable under most of the stability criteria.

The stable scenarios of the subsistence fishers are $q=5,7,1,3,6,8,2,4,11,9$ and 12; these states were disposed in increasing order, with preference for scenarios 5 and 1 . These states could represent solutions for the fishing conflict in the floodplain lake because the subsistence and commercial fishers accept IBAMA's strategy.

In IBAMA's case, under the first hypothesis, we have as stable scenarios, in increasing order, $q=1,3,2$ and 4 . This result shows that the choice of the strategy restrict the use of fishing gears is the most important for the mediator. When the payoff under these stable scenarios is analyzed, we observe that the manager prefers the situation in which both fishers accept its decision while applying restrictions against some fishing gears. For the second hypothesis, IBAMA has as stable scenarios $\mathrm{q}=5,6$ and 8 , where the strategy "prohibit commercial fishing" in the floodplain lake is dominant. The mediator's preference is to obtain a consensual agreement between resource users $(\mathrm{q}=5)$.

\subsection{Equilibrium Analysis}

The results of the equilibrium analysis were divided into two processes due to differences in IBAMA's preferences, previously described as hypotheses 1 and 2. Regarding the first hypothesis, the scenarios $q=1,2,3$ and 4 are stable for all actors. Therefore, it is likely that the selection of the strategy that restricts the use of some fishing gears holds a sole consensual solution for the conflict. To obtain the agreement of both kinds of fishers for this strategy, the first hypothesis regarding IBAMA's goals, IBAMA will face obstacles in convincing the commercial fishers to accept this strategy for fishing management. When the second hypothesis is considered, scenarios $\mathrm{q}=5,6$ and 8 are in equilibrium. In this case, scenario $\mathrm{q}=6$ demonstrates more stability under all criteria, and as in hypothesis 1, IBAMA will face obstacles in convincing the commercial fisher to accept the prohibition of commercial fishing in the lake. The sensibility analysis, which evaluates the robustness of the equilibrium through stochastic oscillations in the decision maker's preferences, has demonstrated that the results are consistent because they do no change between scenarios after the payoff functions are changed. 


\section{Discussion}

Factors such as the large territorial area contribute to the failure of the centralized management of natural resources developed by the Brazilian government during the last three decades. This absence of the government is critical in the Amazonian region and encourages the appearance of non-governmental initiatives developed by inhabitants of riverine villages through a process called "lake fishing agreement", in an attempt to avoid the total depletion of fishing resources (Souza \& Freitas, 2010). In our view, this is non-official management that attempts to change a situation from open access to the resource to a situation of restraining access through the building of collective control mechanisms. However, the absence of a legal baseline was an incentive to the occurrence of conflicts between riverine people and commercial fishers (Hartmann, 1989).

In the 1990s, IBAMA began to discuss the fishing agreements, aiming to assure a legal apparatus for the local initiatives related to fishing control and the conservation of floodplain fishing resources (Isaac, Ruffino, \& McGrath, 1998). Essentially, the fishing agreements are a co-management procedure. In addition to a decentralization effort, this federal agency authorized the local offices to formulate fishing regulations in agreement with the federal legislation. In 2004, a Regulation Instruction was published defining the necessary requirements and procedures for the implementation of a fishing agreement as a strategy to prevent environmental and social damages in a more specific way.

Nevertheless, fishing agreements cannot be considered an integrated and absolute strategy of fishing management for the Amazon basin. In some cases, this strategy fails even as an action to avoid fishing conflicts. In fact, fishing conflicts continue to be observed in some areas, even after their implementation because the social sustainability of the agreements fundamentally depend on the riverine organizations' ability to work with internal and external pressures (Castro \& McGrath, 2000).

The concept of "Tyranny of Small Decisions", primarily used in economics (Kahn, 1966) and later adapted to the environmental context (Odum, 1982), states that an individual cannot deliberately plan the destruction of a system that has been collectively resolved but that the cumulative effect of many small individual actions can definitively change it. When this concept is used to evaluate the conflicts over fishery resources in Amazonian lakes, we conclude that agreements among the resource users cannot reach their objectives when an individual defrauds the established regulations because his action against a particular agreement makes way for others to do the same.

Therefore, the analysis of fishing management strategies should be made including local and regional aspects to better understand the process of the establishment of these strategies and economic performance. Without this understanding, the established strategies for the natural resources management in the floodplain lake will not be able to achieve success because they will not inhibit bad faith behavior in connection with fishing agreements.

According to Nandalal and Simonovic (2003), the management of aquatic resources would be a combination of sharing the resources and solving conflicts among actors. An actor, within this context, could be an individual, an organization or an institution that plays an important role in the result of a decision. Within this context, the feasibility of approaches that find a consensual solution could be an important way of promoting the sustainability of the fishery resources in Amazonian floodplains.

Subsistence fishers have traditionally performed fishing in the floodplain lakes. The diversity of species caught by subsistence fishers has been registered by several authors (Batista, Freitas, Silva, \& Freire-Brasil, 2000; Freitas \& Rivas, 2002; Souza \& Freitas, 2010) and can be justified for the stochasticity inherent in the catch process, as the market presence determining the species is quite weak. The predominance of the subsistence fishing in the floodplain lakes, mainly in the low water season, is probably related to the high concentration of fish in this period of the year due to the retraction in the aquatic environment, which is influenced by flood pulse (Junk, 1989). However, during the high water season, the Amazonian commercial fishers also explore this environment. This "invasion" increases the possibility of conflict between commercial and subsistence fishers.

The analysis of stability showed that subsistence fisher are still interested in peacefully resolving the conflict because they are open to scenarios in which both subsistence fishers and commercial fishers accept the manager decision, independent of the management strategy that has been chosen by IBAMA. When that happens, the possibility of a continuing conflict in this floodplain lake is reduced. Therefore, the subsistence fishers regard IBAMA's participation to be particularly important in the negotiation of the fishing conflict. For the subsistence fisher, the absence of management is the worst scenario. However, the commercial fishers are least interested in official management, probably due to their ability to explore other lakes after the depletion of the resource in a particular lake. The differences in the behavior of the two types of fisher are probably the result of the territoriality instinct inherent to the subsistence fisher, which is absent in the commercial fishers who live in 
urban centers.

We have looked at other possible scenarios of conflict solutions, and they have shown that, although the possibility of resolution exists in social and ecological management, it is very likely that the government agency will face troubles concerning commercial fishers if the decision made is to prohibit commercial fishing. However, the possibility of convincing these fishers to accept management increases when the option that restricts the use of some fishing gears in the floodplain lakes is adopted as a possible resolution for the fishing conflicts.

\section{Acknowledgements}

We are very thankful to the Professor Marc Kilgour for permission to use the GMCR II software and to PIATAM Project-FINEP/PETROBRAS, CNPq and INPA for supporting this research.

\section{References}

Batista, V. S., Inhamuns, A. J., Freitas, C. E. C., \& Freire-Brasil, D. (1998). Characterization of the fisheries in river communities in the low-Solimões River, Amazon region. Fisheries Management and Ecology, 5, 419-428. http://doi/10.1046/j.1365-2400.1998.550419.x

Batista, V. S., Freitas, C. E. C., Silva, A. J. I., \& Freire-Brasil, D. (2000). The fishing activity of the river people in the floodplain of the Central Amazon. In W. J. Junk, J. J. Ohly, M. T. F. Piedade, \& M. G. M. Soares, (Eds.), The Central Amazon Floodplain: Actual use and options for a sustainable management (pp. 417-432). Leiden (Netherlands), Backhuys Publishers.

Berkes, F. (2003). Alternatives to conventional management: Lessons from small-scale fisheries. Environment, 31, 5-19.

Brams, S. J. (1994). Theory of Moves. Cambridge, UK: Cambridge University Press.

Castro, F., \& McGrath, D. (2000). From sector to system: Towards a multidimensional management in the Lower Amazonian Floodplain. In: Cowx, I. G. (Ed.) Management and Ecology of River Fisheries (pp. 388-389). Oxford, UK. Blackwell Science and Publishers. http://dx.doi.org/10.1002/9780470696026.ch27

Fang, L. K., Hipel, W., \& Kilgour, D. M. (1993). Interactive Decision Making: The Graph Model for Conflict Resolution. New York, USA. Wiley \& Sons.

Fang, L., Hipel, W., Kilgour, D. M., \& Peng, X. (2003). A decision support system for interactive decision making - Part II: analysis and output interpretation. Transaction of Systems and Man Cybernetics, 33, 56-66. http://dx.doi.org/10.1109/TSMCC.2003.809360

Fraser, N. M., \& Hipel, K. W. (1979). Solving Complex Conflicts. Transaction of Systems and Man Cybernetics, 9, 805-817. http://doi/10.1109/TSMC.1979.4310131

Freitas, C. E. C., \& Rivas, A. A. F. (2002). Peixe: A sustentabilidade de um recurso comum na Amazônia. In: Freitas, C. E. C., \& Rivas, A. A. F. (Eds.). Amazônia: Uma perspectiva interdisciplinary (pp. 180-225). Manaus, Brasil, Editora da Universidade do Amazonas - EDUA.

Howard, N. (1971). Paradoxes of Rationality: Theory of metagames and political Behavior. Cambridge, UK. Cambridge University Press.

Isaac, V. J., Ruffino, M. L., \& McGrath, D. (1998). In search of a new approach to fisheries management in the middle Amazon. In: T. J., Quinn, II, F., Funk, J., Heifetz, J., Ianelli, J., Power, J., Schweigert, P., Sulliven, \& C. I. Zhang, (Eds.). Fishery Stock Assessment Model (pp. 889-902). Alaska Sea Grant College Program, University of Alaska, Fairbanks, AS-SG 98.

Junk, W. J., Bayley, P. B., \& Sparks, T. E. (1989). The flood pulse concept in river-floodplains systems. In: Dodge, D.P. (Ed.). Proceedings of the International Large River Symposium. Canadian Special Publication of Fisheries and Aquatic Sciences, 106, 110-127.

Junk, W. J. (2000). Mechanisms for development and maintenance of biodiversity in neotropical floodplains, pp. 11-39. In: Gopal, B., Junk, W. J., \& Davis, J. A. (Eds.). Biodiversity in wetlands: assessment function and conservation (pp. 11-39). Leiden, Netherlands. Backhuys Publishers.

Kahn, A. (1966). The tyranny of small decisions: market failures, imperfections, and the limits of economics. Kyklos, 19, 23-47. http://doi/10.1111/j.1467-6435.1966.tb02491.x

Kilgour, D. M., Hipel, K. W., \& Fang, L. (1987). The graph model for conflicts. Automática, 23, 41-55. http://doi/10.1016/0005-1098(87)90117-8

McGrath, D. G., Castro, F., Futemma, C., Amaral, B. D., \& Calabria, J. (1993). Fisheries and the evolution of 
resource management on the lower Amazon floodplain. Human Ecology, 2, 167-195. http://dx.doi.org/10.1007/BF00889358

Nash, J. F. (1951). Non-cooperative games. Annals of Mathematics, 54, $286-295$. http://dx.doi.org/10.2307/1969529

Nandalal, K. D. W., \& Simonovic, P. (2003). State-of-the-art report on systems analysis methods for resolution of conflicts in water resources management. In: Nandalal, K. D. W., \& Simonovic, P. (Eds.). Technical Documents in Hydrology/PC-CP series (pp. 162-177). London, UK.

Odum, W. E. (1982). Environmental degradation and the tyranny of small decisions. BioScience, 32, 728-729. http://dx.doi.org/10.2307/1308718

Sobreiro, T., Freitas, C. E. C., Prado, K. L. L., Nascimento, F. A., Vicentini, R., \& Moraes, A. M. (2010). An evaluation of fishery co-management experience in an Amazonian black-water river (Unini River, Amazon, Brazil). Environment, Development and Sustainability, 12, 1013-1024. http://doi/10.1007/s10668-010-9238-8

Souza, L. A., \& Freitas, C. E. C. (2010). Fishing sustainability via inclusion of man in predator-prey models: A case study in Lago Preto, Manacapuru, Amazonas. Ecological Modelling, 221, 703-712. http://doi/10.1016/j.ecomodel.2009.04.037

Von Neumann, J., \& Morgenstern, O. (1953). Theory of Games and Economic Behavior. New Jersey (United States of America). Princeton University Press.

Zagare, F. C. (1984). Game Theory: concepts and applications. Sage University Paper Series on Qualitative Application in the Social Sciences, California, USA. Sage Publications. 